\title{
APPLYING DIRECT EVAPORATIVE COOLING SYSTEM FOR CONTROLLING ENVIRONMENTAL CONDITIONS IN RABBIT HOUSES
}

\author{
Hend A. M. El-Maghawry *
}

\begin{abstract}
Heat stress is a major problem that faces rabbit's breeders. This problem adversely affects rabbit's growth and reduces the resistance to diseases. The present research was carried out to apply and evaluate the performance of a direct evaporative pad cooling system in rabbit houses to control environmental conditions. The direct evaporative pad cooling system performance was studied as a function of change in pad thickness (10 and $15 \mathrm{~cm})$, water flow rate (3, 5 and $\left.7 \mathrm{~L} / \mathrm{min}^{2} \mathrm{~m}^{2}\right)$ and rabbit stocking density with an approximate average $\left(0.5\right.$ and $\left.1.0 \mathrm{rabbit} / \mathrm{m}^{2}\right)$. Performance evaluation of the evaporative pad cooling system was carried out in terms of temperature reduction, cooling efficiency, temperature-humidity index, daily body weight gain and mortality ratio. The experimental results clarified that values of temperature reduction $\left(7.3\right.$ and $\left.6.8^{\circ} \mathrm{C}\right)$, cooling efficiency $(94.92$ and $90.91 \%)$, temperature-humidity index (26.30 and $\left.27.40^{\circ} \mathrm{C}\right)$, daily body weight gain (38.80 and $38 \mathrm{~g} / \mathrm{rabbit} /$ day) and mortality ratio (0.2 and $0.4 \%$ ) are in the optimal limits under conditions of $15 \mathrm{~cm}$ pad thickness and 5 L/min. $m^{2}$ water flow rate for rabbit stocking densities of 0.5 and 1.0 rabbit $/ \mathrm{m}^{2}$, respectively.

\section{INTRODUCTION}

$\Gamma$

The Egyptian people like so many foods made of rabbits; therefore, rabbit's projects are economically important. Rabbits are often breeding in cages or batteries. The clearest limitation of rabbit production in hot climate regions is this species susceptibility to heat stress. Heat stress occurs mainly when animals are exposed to high direct and indirect solar radiation, high humidity, high ambient temperatures and low wind speed. Willmer et al. (2000) defined heat stress as a stress caused by an extensive range of environmental conditions that motivate physiological strain state within the animal's body, meaning that animals are unable to regulate their thermal balance in a negative way.
\end{abstract}

\footnotetext{
* Lecturer of Agric. Eng., Fac. of Agric., Zagazig Univ.
} 
Mashaly et al. (2004) stated that heat stress is a main problem, especially in countries with extreme climatic conditions. High temperature and radiation grades not only negatively affect production performance, but also prevent immune function.

Forced ventilation, fans, air conditioning, shade, evaporative cooling, feeding management, water spraying, shearing and chilled water are considered most important ways to mitigate heat stress. Most methods rely on evaporative cooling, which is suppressed by high humidity. Water is an excellent cooling factor due to its high latent heat of evaporation and high thermal capacity. Khobragade and Kongre (2016) mentioned that direct evaporative cooling systems are inexpensive and provide an attractive alternative to traditional summer air conditioning systems in hot and arid places. Evaporative cooling system is based on the principle that when damp but unsaturated air meets a wet surface whose temperature is higher than the temperature of the dew point of the air, some water evaporates from the wet surface into the air. Thus, the air is cooled and moistened. Cold and humid air can be used to provide thermal comfort. Porumb et al. (2016) indicated that evaporative cooling technology is relied on heat and mass transfer between air and cooling water. Direct evaporative cooling depends on mechanical and thermal contact between air and water and is characterized by highly efficient in energy use with highly water consumption rates. The major feature of direct evaporative cooling is the simple construction of the equipment, while the main disadvantage is to increase the moisture content of the air, which may be undesirable for some applications.

Many researches were carried out on applying and evaluating the evaporative pad cooling systems in poultry houses, Dağtekin et al. (2006) studied the performance of an evaporative pad cooling system in a broiler poultry house at climate conditions of Mediterranean. They found that the cooling efficiency of the system ranged from 70 to $80 \%$ and the temperature dropped by approximately $10{ }^{\circ} \mathrm{C}$ in the air of the external environment extracted from the poultry house by passing through the cooling pads. Darwesh et al. (2007) investigated the performance standards of rice straw and palm leaf fibers as materials for the evaporative pad cooling system. The experimental results indicated that 
for each pad material, the highest value of temperature reduction was achieved with $15 \mathrm{~cm}$ pad thick and $0.5 \mathrm{~m} / \mathrm{s}$ pad face air velocity. The cooling effect of all rice straw treatments was higher than that of palm leaf fibers. Dağtekin et al. (2009) evaluated an evaporative pad cooling system and examined the distribution of temperature on a long axis in a broiler poultry house. Results showed that the average cooling efficiency value was $69.35 \%$, accompanied by a decrease of $5.19{ }^{\circ} \mathrm{C}$ in the air temperature passing through the pad. As for the increase in air temperature extracted into the poultry house, passing through the pad until it reaches the eject point, was $1.52{ }^{\circ} \mathrm{C}$. Franco et al. (2010) studied the impact of water and airflow on the performance of corrugated cellulose pads and recommended intervals airspeed between 1.0 and 1.5 $\mathrm{m} / \mathrm{s}$. Obtained results showed a reduction in pressure ranging from 3.9 to 11.25 Pascal, depending on the applied water and the thickness of the pad. The air saturation efficiency was between 64 and $70 \%$, and evaporated water ranged from 1.8 to $2.62 \mathrm{~kg} / \mathrm{h} \cdot \mathrm{m}^{2}{ }^{\circ} \mathrm{C}$. Dağtekin $\boldsymbol{e t}$ al. (2011) indicated the relation found between the air velocity passing through the pad, the decrease obtained at air temperature passing through the pad and the cooling efficiency of the cellulosic evaporative cooling pad. They concluded that the most suitable air velocity for the tested pad should be higher than $0.5 \mathrm{~m} / \mathrm{s}$ and less than $1.5 \mathrm{~m} / \mathrm{s}$. Ibrahim et al. (2011) investigated the feasibility of using an evaporative cooling system to improve broilers productivity. Cool and control rooms were used in experiments as two different treatments. Cost analysis proved that the profits were 2723 and 1820 EG.P./life cycle for the cool and control rooms, respectively. The profit of the produced birds in the cool room was about 1.45 times that of the produced birds in the control room. Petek et al. (2012) compared cooling performance between conventional and two stages evaporative pad cooling systems. Results showed that air temperature and relative humidity of the incoming house and the exhausted air in the two-stage pad cooling system were found to be much lower than in the conventional system. Darwesh (2015) investigated the feasibility of using direct evaporative cooling to improve internal air conditions in a laying-hens house. Experimental data revealed that the evaporative cooling system was able and sufficient to maintain internal 
air temperature of the laying-hens house at the required level. The results clarified that the average daily cooling efficiency values during June, July and August were determined by $77.4 \%, 75.6 \%$ and $79.5 \%$, respectively. Karaca $\boldsymbol{e t}$ al. (2016) determined the relation between the temperature decrease of the passing air through cellulose based pad and the water flow rate of pad moistening in the evaporative cooling pad systems. Values of cooling efficiency and the temperature decrease of the air passing through the pad were lower at water flow rate of $6 \mathrm{~L} / \mathrm{min}^{2} \mathrm{~m}^{2}$, while they were close to each other at $\left(2\right.$ and $4 \mathrm{~L} / \mathrm{min} . \mathrm{m}^{2}$ ). The most adequate water flow rate for the experimental conditions was considered $4 \mathrm{~L} / \mathrm{min} . \mathrm{m}^{2}$.

Egyptian summer has high temperatures and low relative humilities. Adult male and female rabbits exposure to <30 THI (temperaturehumidity index) units as severe heat stress during summer, adversely affects their growth and reproductive traits and reduces diseases resistance. Abdel-Samee (1997) studied the impact of improving winter and summer conditions on male growth and does reproduction of New Zealand white rabbits in North Sinai. All parameters of economic importance were reduced in the production of rabbits during hot and humid summer.

Low temperature and high relative humidity within rabbit houses is very important for the production of rabbits during summer. The widely spread rabbit housing system is the total confinement housing system, with fans installed and pads cooling system to reduce internal high temperatures, such a task is performed by evaporative cooling systems.

\section{So, the present research aims to:}

- Apply direct pad evaporative cooling system in rabbit houses to control environmental conditions.

- Investigate some different parameters (Pad thickness, water flow rate and rabbit stocking density) affecting the performance of the applied evaporative cooling system.

\section{MATERIALS AND METHODS}

Experiments were carried out in a private commercial rabbit farm located at El-Obour city, Al Qalyubia Governorate, Egypt (latitude angle of $30.23^{\circ} \mathrm{N}$, longitude angle of $31.48^{\circ} \mathrm{E}$, and mean altitude above sea level 
of $76.19 \mathrm{~m}$ ) during September and October 2017 to study the effect of applying direct evaporative pad cooling system in rabbit houses to control environmental conditions.

\section{Materials}

\subsection{Experimental rabbits}

New Zealand white rabbits with an average age of 7 months and a mean live body weight $(3.25 \mathrm{~kg} \pm 0.12)$ were used in the experiments. Rabbits were housed in battery cages (battery housing system).

\subsection{Rabbit houses}

Two identical rabbit housing systems (A and B) with the same construction properties were involved in this study. Each was different from the other only in the stocking density of rabbits inside the house. Each house (Fig. 1) was oriented in East-West direction and has gross dimensions of $50 \mathrm{~m}$ Length, $12 \mathrm{~m}$ width with a net floor surface area of $600 \mathrm{~m}^{2}$. The ceiling is truss-shaped with $3 \mathrm{~m}$ wall height and $5.2 \mathrm{~m}$ as the highest point of ceiling in the middle of the house. For both houses, rabbit's cages were with standard dimensions of $75 \times 50 \times 40 \mathrm{~cm}$ for length, width and height, respectively. With along the house, each cage was provided with feed and water containers. Cage of each doe was supplied with a metal box with dimensions of $40 \times 35 \times 30 \mathrm{~cm}$ for kindling. Each house was fitted with evaporative cooling pads located at the west wall. The specifications of each house system were as follows:

\subsubsection{House (A):}

Stocking density of 318 breeding New Zealand white rabbits (265 does and 53 bucks) were housed individually in four commercial type battery lines each line consists of two rows of flat deck metal wire cages. The first row of each line was supplied with cages for does and bucks. The second row of each line for growing rabbits was housed in galvanized wire cage battery with standard dimensions of $50 \times 50 \times 40 \mathrm{~cm}$ for length, width and height, respectively. The used batteries were suspended $80 \mathrm{~cm}$ above floor level.

\subsubsection{House (B):}

Four commercial pyramidal type battery lines were used to house a stocking density of 624 breeding New Zealand white rabbits (520 does and 104 bucks) individually. Each line consists of two tiers each of them include two rows of metal wire cages. The lower tier of every line was 
supplied with cages for does and bucks. The upper tier of every line for growing rabbits was housed in galvanized wire cage battery with the same specifications mentioned above. The used batteries were suspended $130 \mathrm{~cm}$ above floor level.

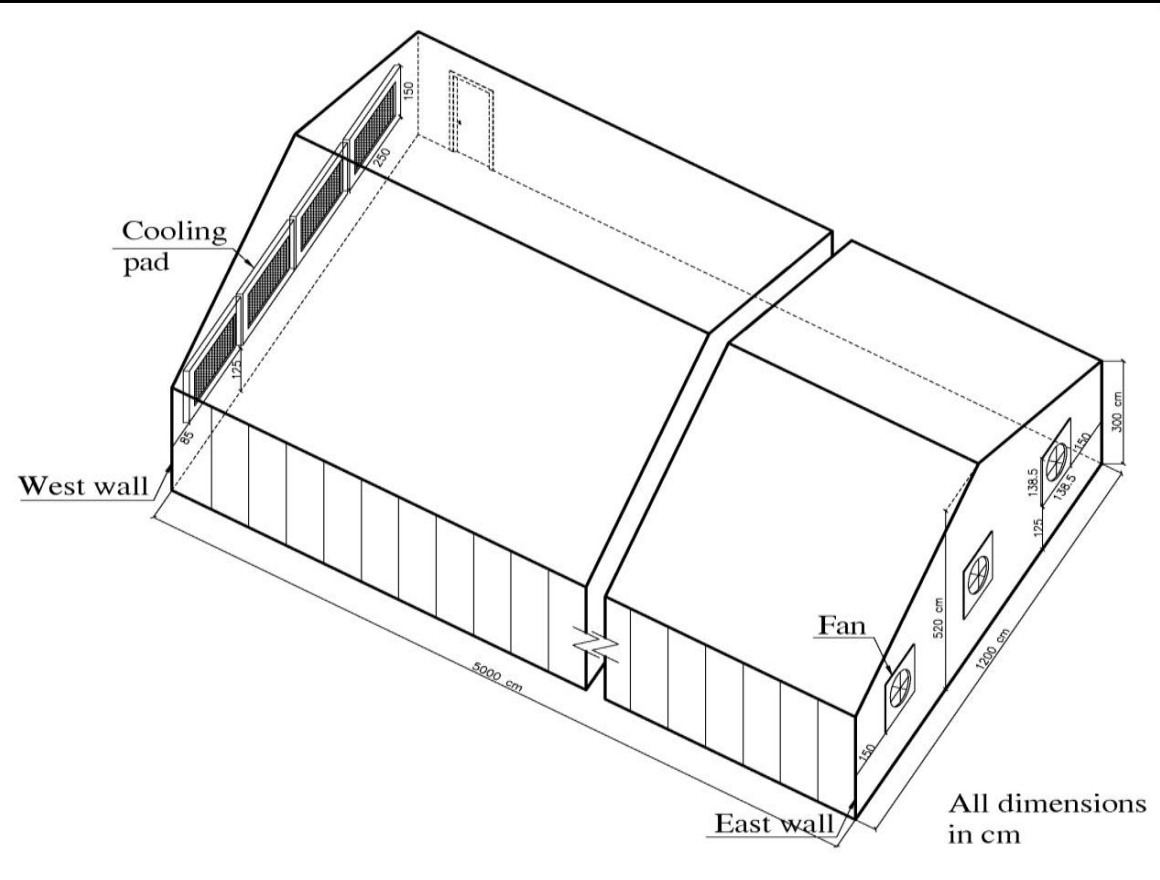

Fig. (1): Isometric view of rabbit house showing cooling pad with fans

\subsection{The direct evaporative pad cooling system:}

The direct evaporative pad cooling system consists of the following:

\subsubsection{Fans}

Three axial flow exhaust fans were installed to draw out the internal air house, thus allowing fresh air to pass through the pads into the house. Specifications of fans were as follow: belt driven, single speed, $138.5 \mathrm{~cm}$ diameter, six blades, $1.2 \mathrm{~m} / \mathrm{s}$ air velocity and $34 \times 10^{3} \mathrm{~m}^{3} / \mathrm{h}$ discharge, 1.5 hp power.

\subsubsection{Pads}

Each house was equipped with four vertical evaporative cooling pads as wetted media in the opposite wall of the exhaust fans (western direction), each having gross dimensions of $2.5 \mathrm{~m}$ width and $1.5 \mathrm{~m}$ height in galvanized steel frame. 


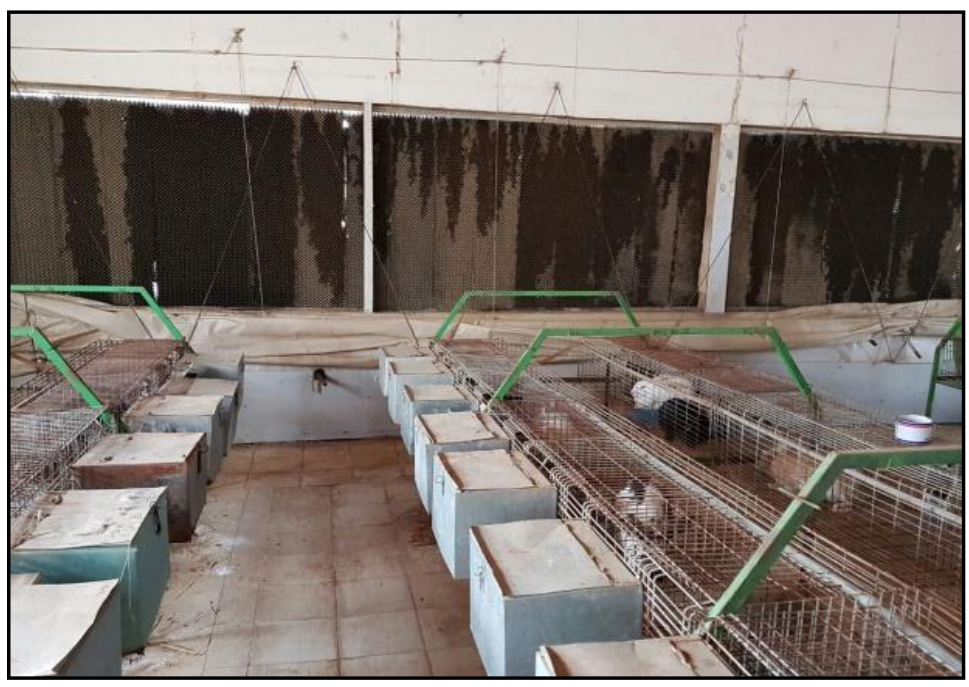

House A

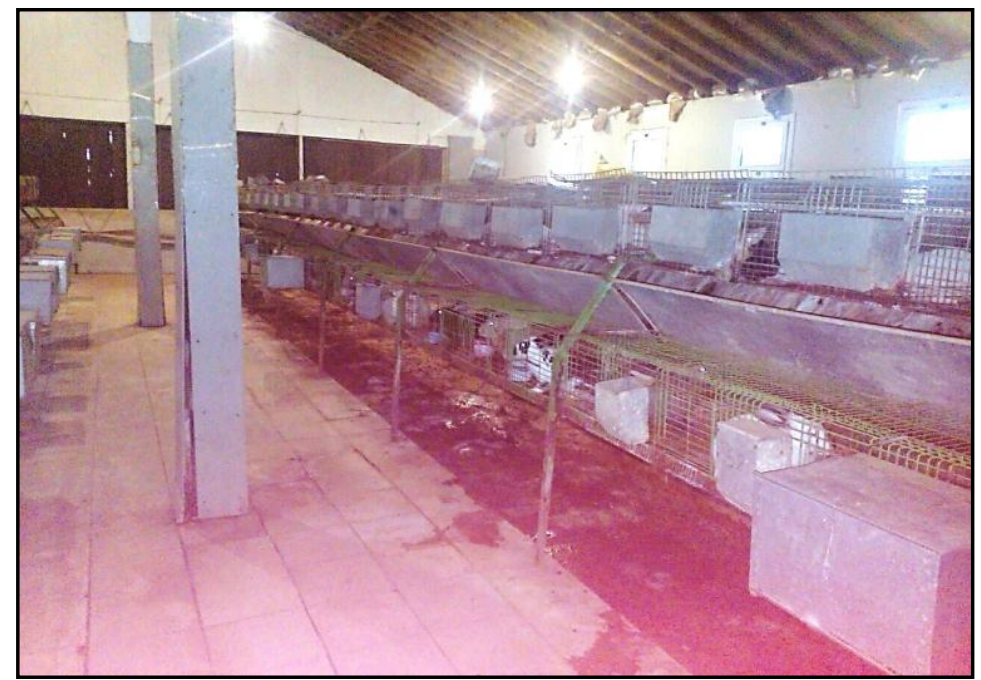

House B

Fig. (2): Photographic view of rabbit houses

Corrugated cellulose evaporative cooling pads have been selected for the experiments, as they are the most widely used. It is a highly efficient evaporative cooling medium that offers long reliable service life, lowpressure drop, maximum cooling, large surface contact for heat and mass exchange between airflow and water that delaying waterfall, ensuring the exchange process lasts longer. Pads are composed of corrugated cellulose 
sheets that are adhesive together alternating the incidence angles on the horizontal $\left(45-45^{\circ}\right)$ so they do not match. Therefore, greater mechanical resistance, greater transport surface and less resistance to air and water circulation were achieved.

Changing the method of stabilization can also prevent the harmful effect of evaporative cooling on nearby nests and newborn rabbits as it reduces the chance of cages exposure to direct air-cooling. In addition, sheets ripple length and width, the incidence angles and pad thickness are considered the most distinctive engineering parameters.

\subsubsection{The evaporative cooling unit}

Specifications of the used evaporative cooling unit components can be clarified as follows:

- Two water tanks with net volume of 250 liters per tank were used for water storage and recirculation for each house. The tank was sited outside the house at $60 \mathrm{~cm}$ under house floor level and at $1.25 \mathrm{~m}$ distance from the cooling pads.

- A water pump of $0.75 \mathrm{hp}(250 \mathrm{~L} / \mathrm{min})$ was used to pump water into pad through water distribution system for each house. The recirculation pump is used to drip the water on the pad top side and thus maintain the moisture of the pads during airflow through them. To make sure all the media are wet; usually more water is pumped than can evaporate and discharge excess water from the bottom to a gutter. The automatic refill system replaces evaporated water. The water flow rates of the pad have been changed with the valve set in the line of water pumping, so that the water flow rate can be adjusted through the tube of water distribution.

- Pads were wetted with the poured water from water inlet perforated pipe, which was settled on the middle top of the unit frame, by a polyvinyl chloride pipe (PVC) $25.4 \mathrm{~mm}$ diameter and $7.5 \mathrm{~m}$ long. 1.5 $\mathrm{mm}$ diameter holes were pierced in a line about $5 \mathrm{~cm}$ apart along the upper side of the pipe which its end was covered, therefore water was distributed on the top face of the evaporative pad unit and thus water evenly on the face of the pad. Bottom gutter is located below the cooling pads to collect and return water to the water tank where it can be repumped to the cooling pads.

\section{Methods}


Experiments were conducted to investigate the performance of the direct evaporative cooling system, which was applied in the rabbit houses to control environmental conditions.

\subsection{Experimental conditions}

The performance of the direct evaporative cooling system was studied under the following experimental conditions:

- Two different pad thicknesses (10 and $15 \mathrm{~cm}$ ).

- Three different water flow rates $\left(3,5\right.$ and $\left.7 \mathrm{~L} / \mathrm{min}^{2} \mathrm{~m}^{2}\right)$ of pad surfaces.

- Two rabbit stocking densities (house A and B contain 318 and 624 breeding rabbits with an approximate average of 0.5 and 1.0 $\mathrm{rabbit} / \mathrm{m}^{2}$, respectively).

\subsection{Experimental procedure}

The experimental work involved measurements of both outdoor and indoor environmental parameters (represented by air temperature and relative humidity) which were recorded five times a day at (9:00), (11:00), (13:00), (15:00) and (17:00) under different experimental conditions.

Three readings for the air temperature and relative humidity were carried out at three different positions behind the pad and the average of these readings was calculated. The readings were taken one meter and half apart along the transmission of air from the pad to the fan and at rabbit cages level of $80-130 \mathrm{~cm}$ above the ground, which was considered the most representative of the rabbit environment. Dry-bulb temperature and relative humidity of outdoor air were measured using digital Hygrothermometer anemometer and $1.5 \mathrm{~m}$ away from the pads. Water flow rate was measured by allowing water to fill a storage tank of known volume with recorded time and the measured flow rate was kept constant throughout each treatment.

Growth performance measurements included (daily body weight gain from 50 to 60 days of age and mortality ratio) were recorded every ten days of each treatment throughout the growth out period.

\subsection{Measurements and determinations}

Performance evaluation of the direct evaporative pad cooling system was carried out under the following indicators: 


\section{- Temperature reduction}

The difference between the temperature outside the house $\left(T_{o}\right)$ and air temperature inside the house $\left(T_{i}\right)$ is used as an important parameter to describe the cooling performance of evaporative cooling system. The temperature reduction describes the cooling effect inside the houses and easy criteria to evaluate the efficiency of cooling system. Temperature reduction was calculated using the following formula:

$$
\Delta \mathrm{T}=T_{o}-T_{i}
$$

Where, $\Delta \mathrm{T}$ is the cooling effect, ${ }^{\circ} \mathrm{C}$.

\section{- Cooling efficiency:}

The cooling system efficiency was estimated at different operation conditions using the following Equation (Koca et al., 1991):

$$
\eta=\frac{T_{d b i}-T_{d b o}}{T_{d b i}-T_{w b i}} \times 100
$$

Where: $\eta$ is cooling efficiency (\%) and $T_{d b i}, T_{d b o}, T_{w b i}$ are the dry-bulb temperature of the air entering the pad, the dry-bulb temperature of the air exiting the pad, and the wet-bulb temperature of the air entering the pad $\left({ }^{\circ} \mathrm{C}\right)$, respectively. As the wet-bulb temperature of the air, entering to the pad was determined from a psychometric diagram.

\section{- Temperature-humidity index:}

The temperature-humidity index (THI) (an indicator of thermal comfort level for animals in an enclosure) was calculated according to LPHSI (1990) which was modified for rabbit by Marai et al. (2001) and given as:

$$
T H I=d b-[(0.31-0.31 \times R H)(d b-14.4)]
$$

Where: $T H I$ - Temperature-humidity index $\left({ }^{\circ} \mathrm{C}\right)$;

$$
d b \text { - Dry-bulb temperature }\left({ }^{\circ} \mathrm{C}\right) \text {; }
$$

$R H$ - Air relative humidity (\%).

The values of $T H I$ obtained for the temperate and subtropical region are classified as: $\angle 27.8^{\circ} \mathrm{C}=$ absence of heat stress, $27.8-28.9^{\circ} \mathrm{C}=$ moderate heat stress, $28.9-30^{\circ} \mathrm{C}=$ severe heat stress and above $30^{\circ} \mathrm{C}=$ very severe heat stress (Marai et al., 2002).

\section{- Daily body weight gain:}


Daily body weight gain (g/rabbit/day) from 50 to 60 days of age was calculated by subtracting the average initial live body weight from the average final body weight.

\section{- Mortality ratio:}

Mortality ratio was estimated during the experimental periods as a percent to the initial number of rabbits. The following equation was applied to obtain the mortality ratio:

Mortalityratio $(\%)=\frac{\text { Initial number }- \text { final number }}{\text { Initial number }} \times 100$

\section{RESULTS AND DISCUSSIONS}

The discussion will cover the obtained results under the following heads:

\section{The climatic conditions of the experimental region}

The climatic conditions outside the house, represented by the intensity of solar radiation, daylight hours, air ambient temperature, air relative humidity and time of year are the most important factors affecting any evaporative cooling system and therefore the environmental conditions inside the house. A typical day has been selected for the diagram shown in Fig. 3 to illustrate the climatic conditions variation outside the house (ambient air temperature and relative humidity) with respect to time of the day during experimentation.

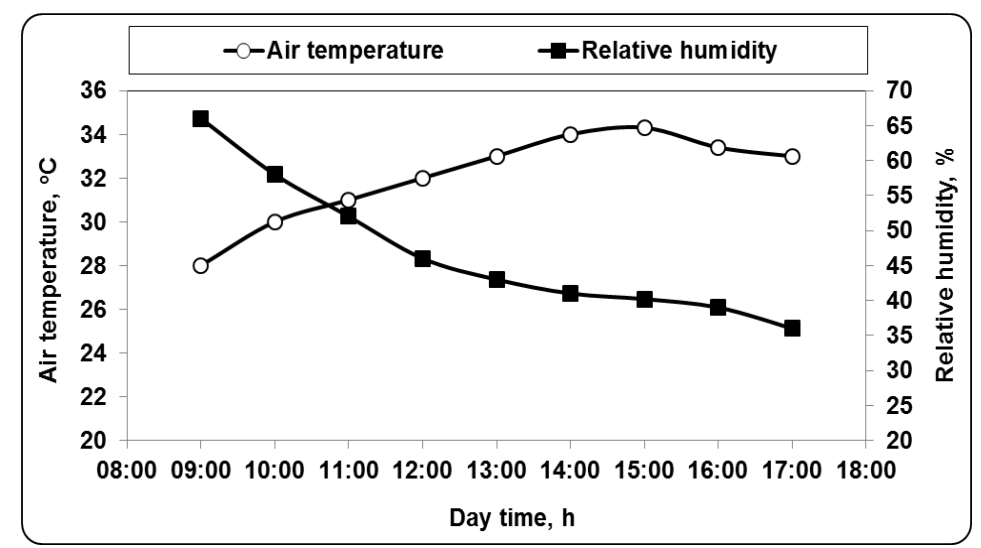

Fig. (3): The climatic conditions of the experimental region (dated on 15 September 2017)

The recorded data were carried out on dated 15 September 2017 from 9:00 to 17:00. Ambient air temperature varied from 28 to $34.3{ }^{\circ} \mathrm{C}$. It gradually increases from morning hours and reached its highest value of 
$34.3{ }^{\circ} \mathrm{C}$ at 15:00. While air relative humidity varied from 66 to $40.2 \%$ from 9:00 to 15:00. Recorded data for other days were approximately the same and took the same behavior as the previous mentioned day of 15 September 2017.

\section{Effect of some different parameters on temperature reduction}

Representative values of the temperature decrease of the air passing through the pad versus day hours for the two rabbit housing systems (A and B) under different water flow rates are given in Fig. 4.

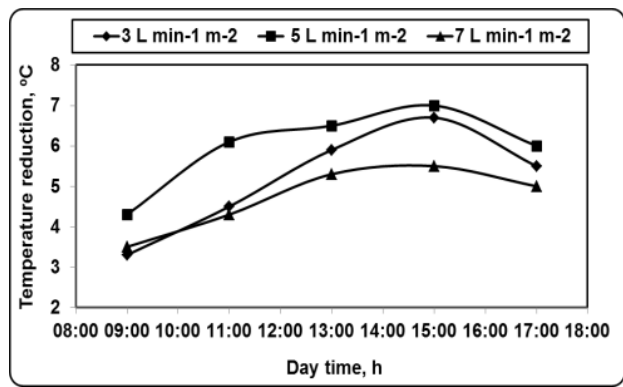

House A (10 cm pad thickness)

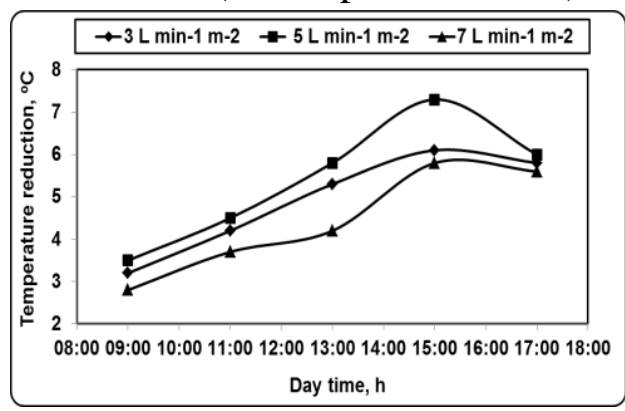

House A (15 cm pad thickness)

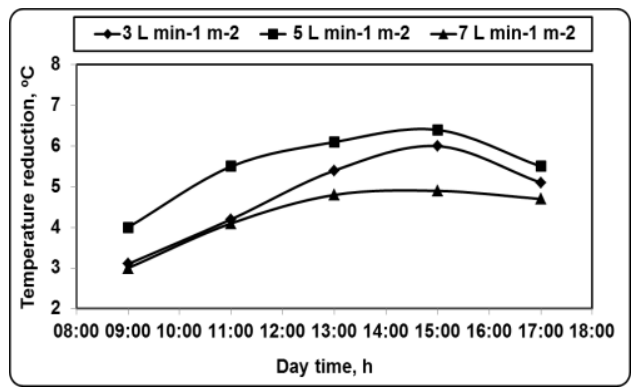

House B (10 cm pad thickness)

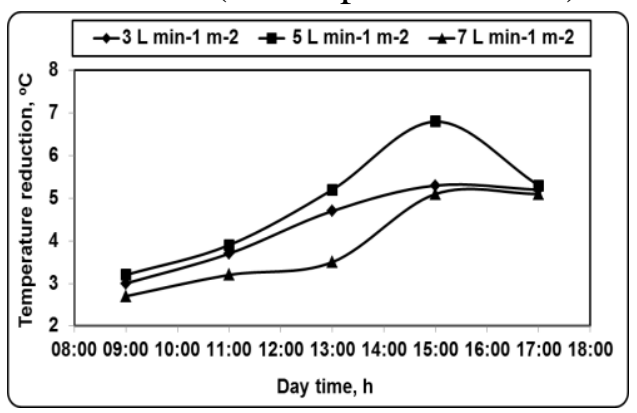

House B (15 cm pad thickness)

Fig. (4): Effect of water flow rate and pad thickness on temperature reduction under different rabbit stocking densities

For both housing systems, it can be noticed that all values of temperature reduction increased progressively under different water flow rates with air ambient temperature during day hours up to 15:00 where the temperature reduction reached their maximum values. After 15:00, temperature reduction decreased may be due to the reduced effect of air ambient temperature. It was observed that the temperature reduction 
values of housing system (A) were higher than housing system (B). The temperature reduction reached the maximum value of $7.3{ }^{\circ} \mathrm{C}$ at $15: 00$ for housing system (A). While the temperature reduction reached the maximum value of $6.8{ }^{\circ} \mathrm{C}$ at $15: 00$ for housing system (B) under conditions of $5 \mathrm{~L} / \mathrm{min} \cdot \mathrm{m}^{2}$ and $15 \mathrm{~cm}$ pad thickness. The temperature reduction values of housing system (B) are lower than the temperature reduction values of housing system (A) because of the increase of the stocking density, which increases air temperature inside the house, thus reducing temperature reduction values.

From the observations, it was seen that the temperature reduction of air passing the pad at $7 \mathrm{~L} / \mathrm{min} . \mathrm{m}^{2}$ water flow rate was less than the other flow rates $\left(3 \mathrm{~L} / \mathrm{min} \cdot \mathrm{m}^{2}\right.$ and $\left.5 \mathrm{~L} / \mathrm{min} \cdot \mathrm{m}^{2}\right)$. This can be attributed to that the increased water flow rate, increases the resistance to the airflow thus decreases pad porosity, due to the excessive water flow that causes the curved surfaces at the pad covered with water with reduced total surface area. This is in agreement with Ylldız et al. (2010). However, the temperature reduction values at $3 \mathrm{~L} / \mathrm{min} . \mathrm{m}^{2}$ water flow rate were lower in comparison with $5 \mathrm{~L} / \mathrm{min} \cdot \mathrm{m}^{2}$ water flow rate. The reason behind this may be interpreted by insufficient water flow rate.

\section{Effect of some different parameters on cooling efficiency}

Effect of different water flow rates versus day hours for the two rabbit housing systems (A and B) on cooling efficiency are given in Fig. 5.

Concerning the effect of water flow rate on the cooling efficiency, results represented in Fig. 5 show that increasing water flow rate from 3 to 5 $\mathrm{L} / \mathrm{min} . \mathrm{m}^{2}$, increased cooling efficiency from 86.89 to $94.92 \%$ for housing system (A) and from 75.50 to $90.91 \%$ for housing system (B) under conditions of $15 \mathrm{~cm}$ pad thickness. Any further increase in water flow rate more than 5 up to $7 \mathrm{~L} / \mathrm{min} . \mathrm{m}^{2}$, cooling efficiency decreased from 94.92 to 68.72 and from 90.91 to $60.43 \%$ for housing systems (A) and (B), respectively. The increase in cooling efficiency by increasing water flow rate may be attributed to the amount of the water flow rate, which was enough to wet the pad area completely and thoroughly. This result is in agreement with Gunhan et al. (2007) who clarified that the cooling efficiency is increased with increasing water flow rate until the pads are suitably moist. While the continuous increasing in water flow 
rate leads to lower cooling efficiency due to increase the relative humidity and reduce the surface area exhibition to the air from the inlet.

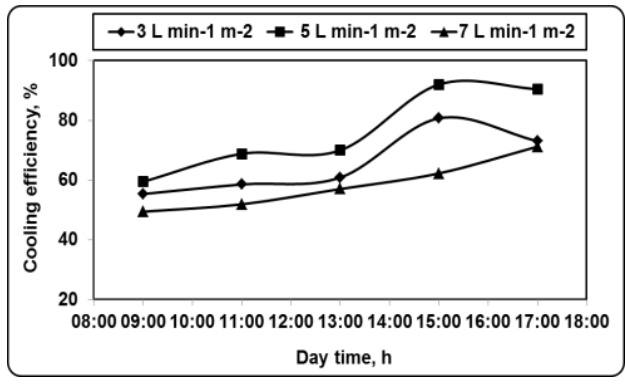

House A (10 cm pad thickness)

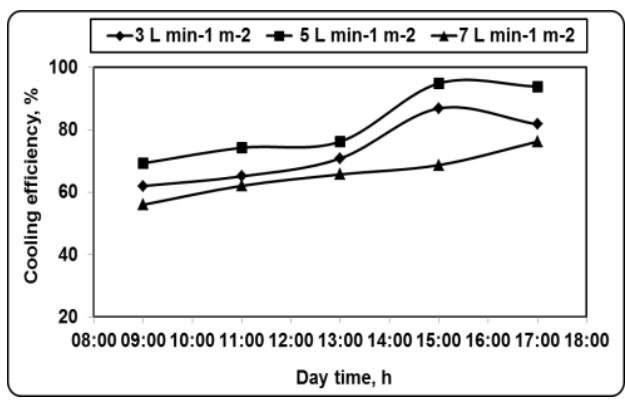

House A (15 cm pad thickness)

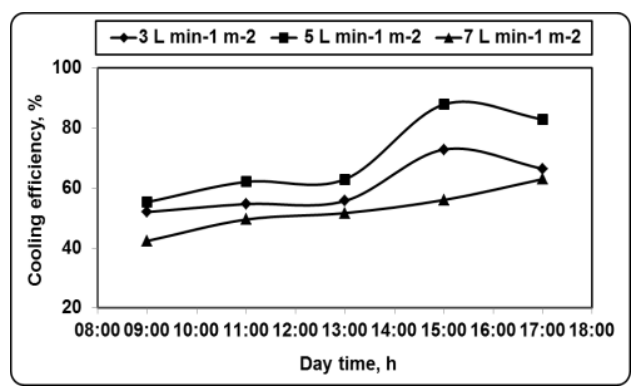

House B (10 cm pad thickness)

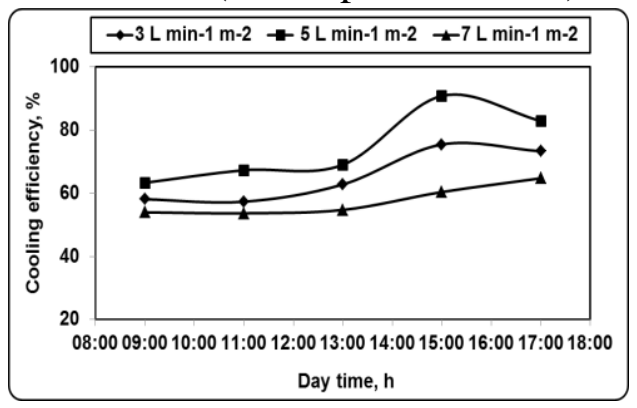

House B (15 cm pad thickness)

Fig. (5): Effect of water flow rate and pad thickness on cooling efficiency under different rabbit stocking densities

Relating to the effect of pad thickness on the cooling efficiency inside both houses, results showed that cooling efficiency increased with increasing pad thickness. Increasing pad thickness from 10 to $15 \mathrm{~cm}$ increased cooling efficiency from 92.03 to $94.92 \%$ for housing system (A) and from 87.91 to $90.91 \%$ for housing system (B) under conditions of $5 \mathrm{~L} / \mathrm{min} . \mathrm{m}^{2}$. The low performance of $10 \mathrm{~cm}$ evaporative cooling pad thickness could be attributed to the increased relative humidity coupled with rabbits breathes, which may lead to reduce ventilation efficiency and cause respiratory health problems. On the other hand, the high performance of $15 \mathrm{~cm}$ evaporative cooling pad thickness is due to providing higher contact surface area between air and water, which increases the passing time of air and reduces the speed of the airflow thus 
increasing the cooling efficiency. These results are in line with those presented by (Liao and Chiu, 2002).

\section{Effect of some different parameters on temperature-humidity index}

Representative values of temperature-humidity index versus day hours for both rabbit housing systems through various water flow rates are given in Fig. 6. The obtained results show that temperature-humidity index values increased gradually under different water flow rates during day hours up to 15:00 where the temperature-humidity index reached their maximum values then decreased.

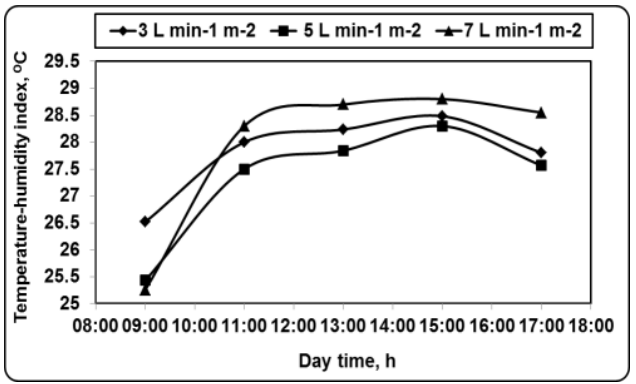

House A (10 cm pad thickness)

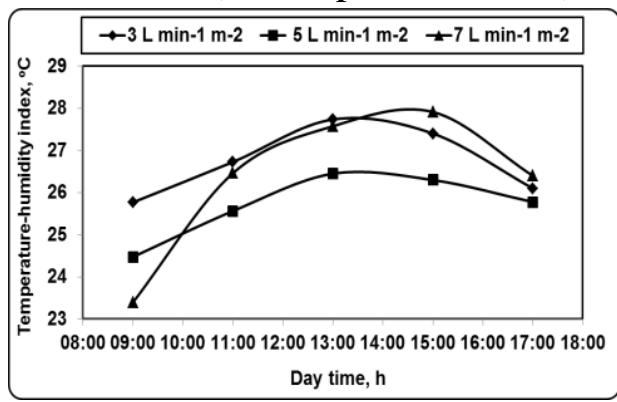

House A (15 cm pad thickness)

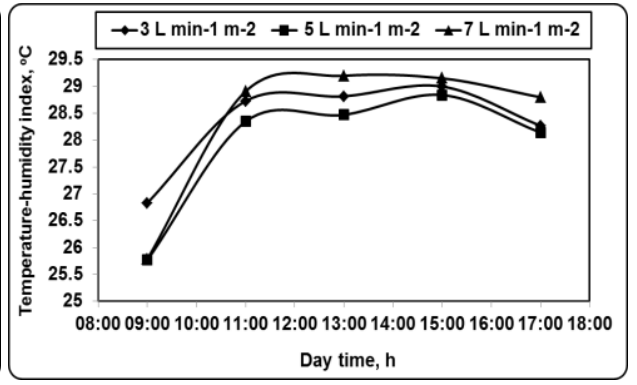

House B (10 cm pad thickness)

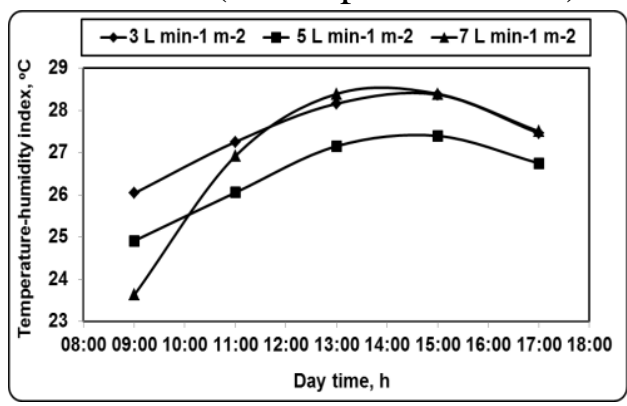

House B (15 cm pad thickness)

Fig. (6): Effect of water flow rate and pad thickness on temperaturehumidity index under different rabbit stocking densities

The afternoon and beyond (from 13:00 to 15:00) are the best periods showing the maximum effect of the evaporative cooling system, as rabbits in this period are exposed to the maximum values of heat stress. Obtained results showed that for housing system (A) temperaturehumidity index values were lower than housing system (B). The 
temperature-humidity index reached values of 26.30 and $27.40{ }^{\circ} \mathrm{C}$ at 15:00 for housing systems (A) and (B), respectively, under conditions of $5 \mathrm{~L} / \mathrm{min} . \mathrm{m}^{2}$ and $15 \mathrm{~cm}$ evaporative cooling pad thickness. Therefore, the THI values were in case of absence of heat stress as reported by (Marai et al., 2002). The reason for the lower values of temperature-humidity index of housing system (A) than the temperature-humidity index values of housing system (B) is due to that the temperature in housing system (B) was higher than housing system (A) $\left(28.7{ }^{\circ} \mathrm{C}\right.$ vs. $\left.27.6{ }^{\circ} \mathrm{C}\right)$ because of the increase in stocking density. Higher temperatures increased water evaporation in the house so that the relative humidity in housing system (B) is higher than housing system (A) (70.6\% vs. $68.2 \%)$. The higher temperature and relative humidity in housing system (B) tends to increase THI in housing system (B) higher than housing system (A).

Concerning the effect of water flow rate on the temperature-humidity index, results show that the minimum values of the temperature-humidity index were observed at 15:00 under water flow rate of $5 \mathrm{~L} / \mathrm{min} . \mathrm{m}^{2}$, while the highest values were observed under water flow rate of $7 \mathrm{~L} / \mathrm{min} . \mathrm{m}^{2}$ for both housing systems. It was noted that the increase of water flow rate from 5 to $7 \mathrm{~L} / \mathrm{min}^{2} \mathrm{~m}^{2}$, was accompanied with an increase in the temperature-humidity index from 26.30 to 27.92 and from 27.40 to 28.40 ${ }^{\circ} \mathrm{C}$ for housing systems (A) and (B), respectively, under conditions of 15 $\mathrm{cm}$ evaporative cooling pad thickness. That is may be attributed to the excessive flow of water which decrease pad porosity and lead to decrease the chance of projecting the air flow to water, resulting in increasing the relative humidity inside the house thus increasing the temperaturehumidity index.

\section{Effect of some different parameters on daily body weight gain}

Relating to the effect of cooling pad thickness on the daily body weight gain for both housing systems under different water flow rates, obtained results in Fig. 7 showed that for housing system (A) daily body weight gain values were 36.6, 37.2 and 35.7 and $38.4,38.8$ and $37 \mathrm{~g} / \mathrm{rabbit} /$ day under water flow rates of 3,5 and $7 \mathrm{~L} / \mathrm{min} . \mathrm{m}^{2}$ and for pad thicknesses of 10 and $15 \mathrm{~cm}$, respectively. While values of daily body weight gain for housing system (B) were $34,36.3$ and 33.1 and $37.2,38$ and 36.1 $\mathrm{g} / \mathrm{rabbit} / \mathrm{day}$ under the same previously mentioned conditions. 


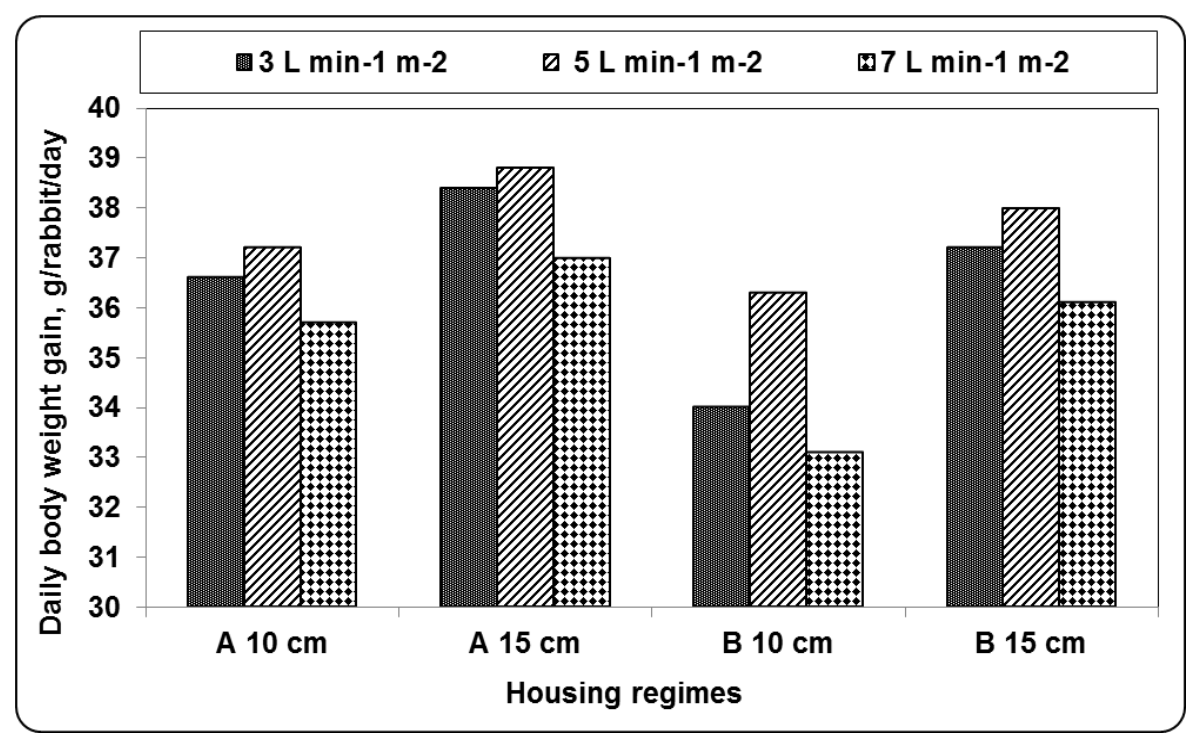

Fig. (7): Effect of water flow rate and pad thickness on daily body weight gain under different rabbit stocking densities

Concerning the effect of water flow rate on the daily body weight gain, results illustrated that the maximum values of daily body weight gain were 38.8 and $38 \mathrm{~g} / \mathrm{rabbit} /$ day for housing systems (A) and (B), respectively under water flow rate of $5 \mathrm{~L} / \mathrm{min} . \mathrm{m}^{2}$ and $15 \mathrm{~cm}$ pad thickness. The decrease in daily body weight gain may be attributed to that the exposure of rabbits to heat stress lead to suppression of hypothalamic appetite center, reduce the feed intake and this affects rabbit's production performance adversely.

\section{Effect of some different parameters on mortality ratio}

Fig. 8 shows the relationship between thickness of pad cooling and mortality ratio for both housing systems under different water flow rates. Concerning housing system (A), data showed that mortality ratio values were $1.3,0.8$ and $2.5 \%$ at pad thickness of $10 \mathrm{~cm}$ and $0.6,0.2$ and $1 \%$ at pad thickness of $15 \mathrm{~cm}$ under water flow rates of 3,5 and $7 \mathrm{~L} / \mathrm{min} . \mathrm{m}^{2}$, respectively. While mortality ratio values for housing system (B) were 2.5, 1.6 and $3.3 \%$ at pad thickness of $10 \mathrm{~cm}$ and 1.5, 0.4 and $2 \%$ at pad thickness of $15 \mathrm{~cm}$ under the same conditions mentioned above. 


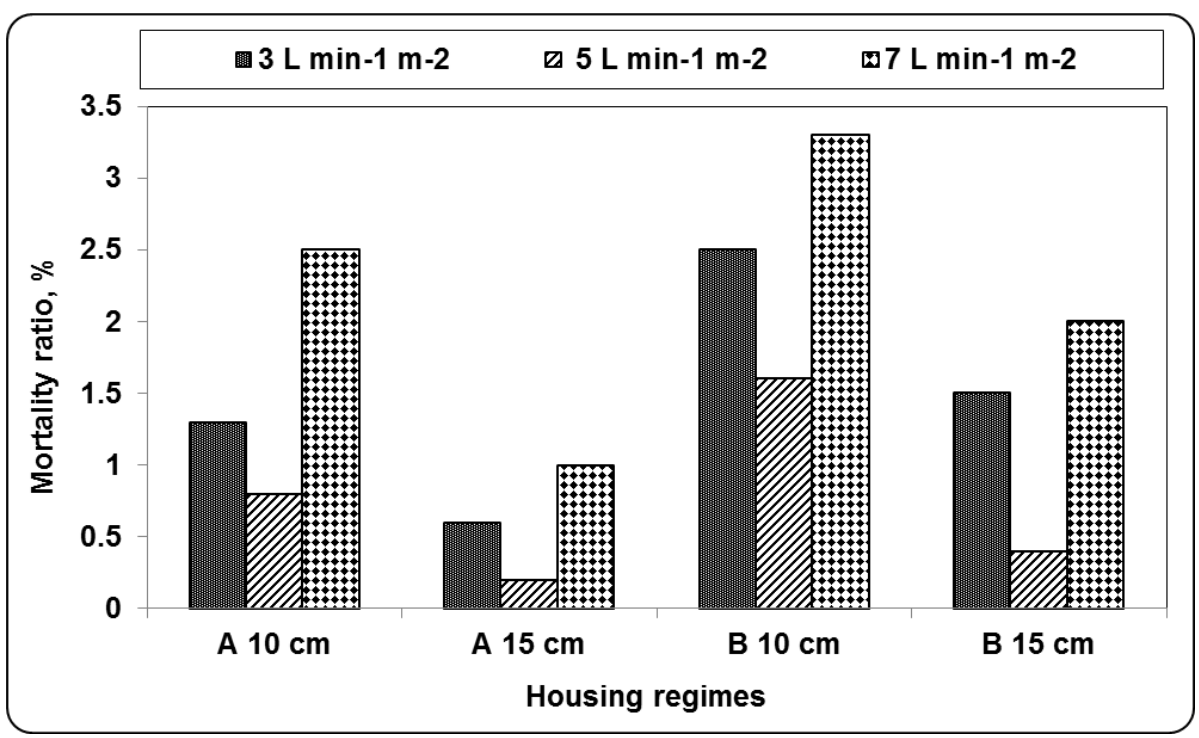

Fig. (8): Effect of water flow rate and pad thickness on mortality ratio under different rabbit stocking densities

Relating to the effect of water flow rate on the mortality ratio, results showed that mortality ratio decreased with increasing water flow rate up to $5 \mathrm{~L} / \mathrm{min} . \mathrm{m}^{2}$ then increased. The minimum values of mortality ratio of 0.2 and $0.4 \%$ were obtained under pad thickness of $15 \mathrm{~cm}$ and 5 $\mathrm{L} / \mathrm{min}^{2} \mathrm{~m}^{2}$ water flow rate for housing systems (A) and (B), respectively. This could be attributed to that the resulting heat stress with increasing water flow rate and decreasing pad thickness may lead to cause does miscarry; ignore the newborn, birth outside the nest box on the wire floor instead of in the nest box and direct detrimental effect on the sensitive offspring. In addition, rabbits can die from heat stress, leading to higher mortality.

\section{CONCLUSION}

The present research was carried out to study the effect of applying direct evaporative pad cooling system in rabbit's houses to control environmental conditions.

From the resulting data, it can be summarized that evaporative pad cooling thickness as well as water flow rate and rabbit stocking density are considered essential variables influencing the environmental control of rabbit's houses. 
The obtained experimental results under conditions of $15 \mathrm{~cm}$ evaporative pad cooling thickness and water flow rate of $5 \mathrm{~L} / \mathrm{min} . \mathrm{m}^{2}$ were as follow:

- Case of house (A) with rabbit stocking density of an approximate average of $0.5 \mathrm{rabbit} / \mathrm{m}^{2}:\left(7.3{ }^{\circ} \mathrm{C}\right)$ temperature reduction, $(94.92 \%)$ cooling efficiency, $\left(26.30^{\circ} \mathrm{C}\right)$ temperature-humidity index, $(38.80$ $\mathrm{g} / \mathrm{rabbit} /$ day $)$ and $(0.2 \%)$ mortality ratio.

- Case of house (B) with rabbit stocking density of an approximate average of $1.0 \mathrm{rabbit} / \mathrm{m}^{2}:\left(6.8^{\circ} \mathrm{C}\right)$ temperature reduction, $(90.91 \%)$ cooling efficiency, $\left(27.40{ }^{\circ} \mathrm{C}\right)$ temperature-humidity index, $(38.00$ $\mathrm{g} / \mathrm{rabbit} /$ day) and $(0.4 \%)$ mortality ratio.

\section{REFERENCES}

Abdel-Samee, A.M. (1997). Response of New Zealand white rabbits to thermal stress and its amelioration during winter and summer of North Sinai, Egypt. Journal of Arid Environments 36: 333-342.

Dağtekin M., C. Karaca and Y. Yıldız (2009). Long Axis Heat Distribution in a Tunnel-Ventilated Broiler House Equipped With an Evaporative Pad Cooling System. Anim. Prod. Sci., 49: 11251131.

Dağtekin, M., C. Karaca and Y. Yıldız (2006). Performance Characteristics of a Pad Evaporative Cooling System in a Broiler House in a Mediterranean Climate. Biosyst. Eng., 103: 100-104.

Dağtekin, M., C. Karaca, Y. Yildiz, A. Basçetinçelik and Ö. Paydak (2011). The effects of air velocity on the performance of pad evaporative cooling systems. African Journal of Agricultural Research 6 (7): 1813-1822.

Darwesh, M. R. (2015). Effect of evaporative cooling system on microclimatic circumstances of commercial closed laying-hens house under delta-zone climatic conditions. Misr J. Agric. Eng., 32 (2): $885-908$.

Darwesh, M., S. Abouzaher, T. Fouda and M. Helmy (2007). Effect of using pad manufactured from agricultural residues on the performance of evaporative cooling system. Misr J. Agric. Eng., 24(4): 1023- 1043. 
Franco, A., D.L.Valera, A. Madue $\tilde{n}$ and A. Pe $e^{\sim}$ a (2010). Influence of water and air flow on the performance of cellulose evaporative cooling pads used in Mediterranean greenhouses. Trans. ASABE 53 (2): 565-576.

Gunhan, T., V. Demir and A.K. Yagcioglu (2007). Evaluation of the Suitability of Some Local Materials as Cooling Pads. Biosys. Eng., 96: 369-377.

Ibrahim, M. H., E. A. Abdel Ghaffar, M. F. Hassan and A. M. Bayomy (2011). Improve the productivity of broilers using an evaporative cooling system. Misr J. Agric. Eng., 28(4): 1094 1118.

Karaca, C., Y. Yıldız, M. Dağtekin and Z. Gümüş (2016). Effect of water flow rate on cooling effectiveness and air temperature change in evaporative cooling pad systems. Environmental Engineering and Management Journal15 (4): 827-833.

Khobragade, N. N. and S. C. Kongre (2016). Experimental performance of different evaporative cooling pad material of direct evaporative cooler in hot and dry region. International Journal of Innovative Technology and Research (IJTR) 4 (3): 2920 - 2923.

Koca, R. W., W. C. Hughes and L. L. Christianson (1991). Evaporative cooling pads: Test procedure and evaluation. Applied Engineering in Agriculture 7 (4): 485-490.

Liao, C. M. and K. H. Chiu (2002). Wind Tunnel Modeling the System Performance of Alternative Evaporative Cooling Pads in Taiwan Region. Building Environment 37: 177-187.

LPHSI (1990). Livestock and Poultry Heat Stress Indices. Agricultural Engineering Guide. Clemson University, Clemson SC., 29634, USA.

Marai, I. F. M., M. S. Ayyat and U. M. Abd El-Monem (2001). Growth performance and reproductive traits at first parity of New Zealand White female rabbits as affected by heat stress and its alleviation under Egyptian conditions. Tropical Animal Health and Production 33: 1-12. 
Marai, I. F. M., A. A. M. Habeeb and A.E. Gad (2002). Rabbits' productive, reproductive and physiological performance traits as affected by heat stress: a review. Livestock Science 78 (2): 71-90.

Mashaly, M. M., G. L. Hendricks, M. A. Kalama, A. E. Gehad, A. O. Abbas and P. H. Patterson (2004). Effect of heat stress on production parameters and immune responses of commercial laying hens. Poultry Science 83: 889-94.

Petek, M., S. Dikmen and M. M. Oğan (2012). Performance analysis of a two stage pad cooling system in broiler houses. Turk. J. Vet. Anim. Sci. 36(1): 21-26.

Porumb, B., P. Ungureşan, L. F. Tutunaru, A. Şerban and M. Bălan (2016). A review of indirect evaporative cooling technology. Energy Procedia 85: $461-471$.

Willmer P., G. Stone and J. Johnston (2000). Environmental physiology of animals. $1^{\text {st }}$ ed. Blackwell Scientific Publications, Oxford. 672 pp.

Yıldız, Y., C. Karaca, M. Dağtekin (2010). Environmental control in livestock shelters: Ventilation, heating, cooling and illumination (in Turkish) Hasad Yayıncılık Ltd. Şti., P.K. 35, Ümraniye-3470İstanbul.

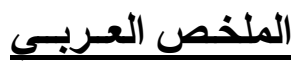

تطبيق نظام التبريد التبخيري المباشر للتحكم في الظروف البيئية داخل عنابر الأرانب

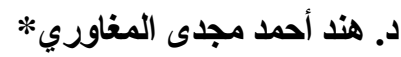

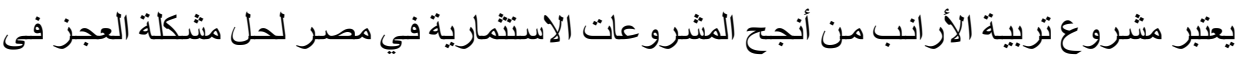

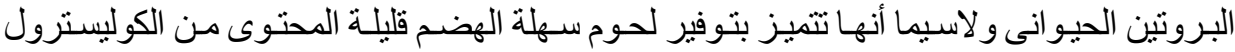

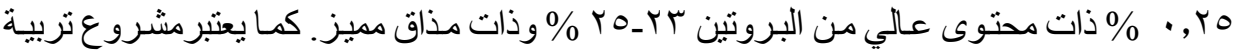

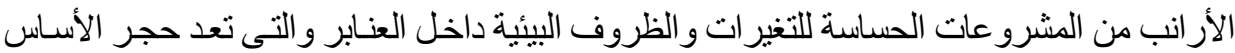

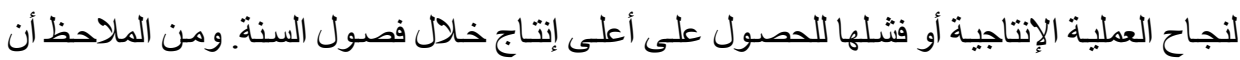

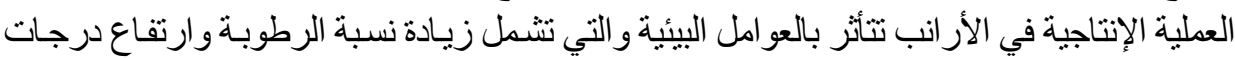

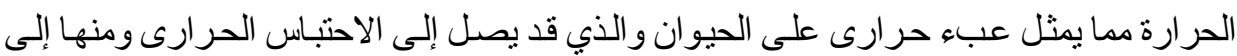

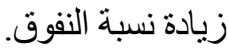

*مدرس بقسم الهندسة الزراعية ـ كلية الزراعة - جامعة الزقازيق 
لذا فإن تربيـة الأر انب بالمنـاطق الحسارة تسـتوجب أن تقام لها عنـابر (مغلقـة أو شبـه مغلقة) ومكيفـة

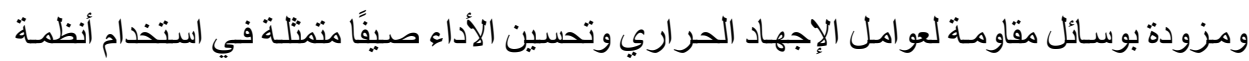
تبريد مختلفة (نظام الرشاثات ـ نظام الضباب - وسائد التبريد التبخيري). ومن ثم فقد أجري هذا البحث بهدف در اسـة تأثير تطبيق نظـام التبريد التبخيري المباثـر باستخدام

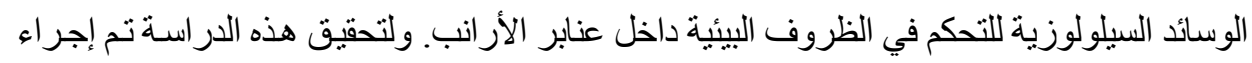
مجمو عة من التجارب تحت عو امل تتخيل مختلفة:

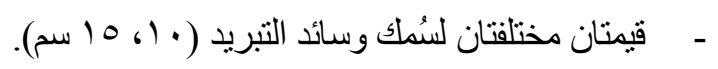

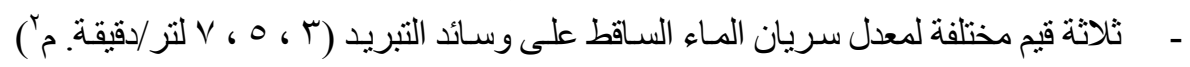

$$
\text { من سطح الخلية. }
$$

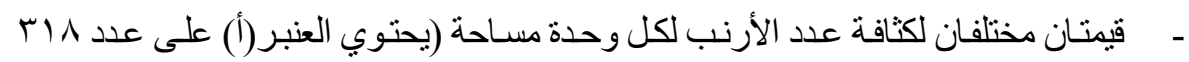

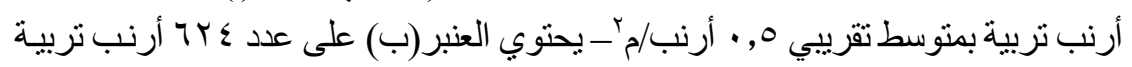

$$
\text { بمتوسط تقريبي ا أرنب/م'ب). }
$$

وقد تم تقييم المعاملات السابقة أخذاً في الاعتبار كلاً من مقدار الإنخفاض في درجة الحرارة، كفاءة التبريد، دليل الحرارة و الرطوبة، الزيادة اليومية في وزن الجسم، نسبة النفوق. وكانت أهم النتائج المتحصل عليها ما يلي:

- إمكانيـة استخدام نظـام التبريد التبخيري المباشـر للتحكم في الظروف البيئيـة داخل عنـابر

$$
\text { الأزرانب. }
$$

- أظهرت النتائج أن كل من مقدار الإنخفاض في درجة الحرارة، كفاءة التبريد، دليل الحرارة

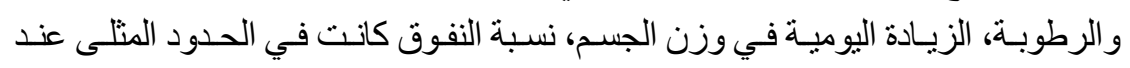

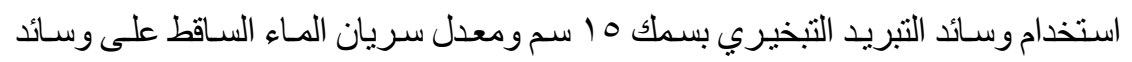

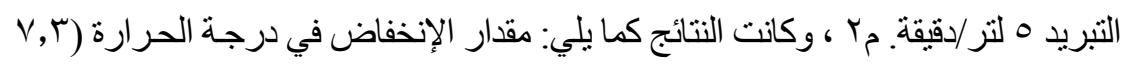

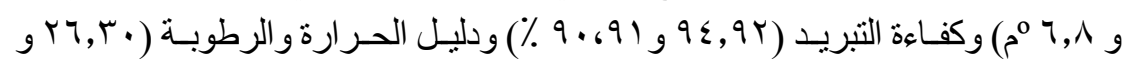

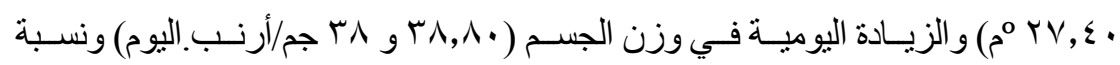
النفوق (ז, • و ع, • ٪) وذلك لكل من العنبر (أ) و العنبر (ب) على الترتيب. 